\title{
Pengaruh Penggunaan Metode Pendidikan Moral Terhadap Peningkatan Pertimbangan Moral Siswa SMP
}

\section{H.M. DJUNAIDI GHONY DAN NUR ALI R.}

Dosen Tetap STAIN Malang

\section{ABSTRACT}

The made of leaming in eadiongmoral educasion widety adopted in Indonesis is the Lecture Question Answer (QA) metrod developed from the Value-Inodestion approads This mechad haslent itself to that negative ine preasion The present study is an attempt

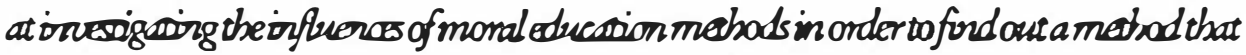
is more appropiose to the charecterisios and the objectives of moral educosion in Indonesia

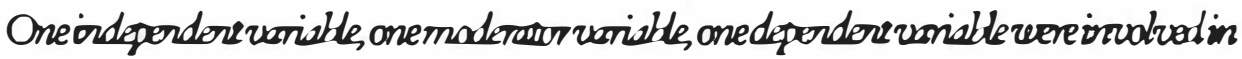
che stucty. This research is experimental in nature and was perforned using a $2 X 2$ fecorial design. The reseanch sebjects were randomly selected from the sudents of SMP IKIPMALANG, and they were also roudomby assigned to perfonn reseanch treasments. The subjects' moral judgment stages were measured using che Koblberg's moval judginent stagestructure. A reorevy anowa was then performal to anshre the data. 


\section{A. Pengantar}

Untuk mendapatkan visi metode pembelajaran terhadap pembelajaran pendidikan moral/pendidikan nilai perlu kiranya mempertimbangkan bagaimana metode diskusi dilema moral memiliki pengaruh terhadap pembelajaran moral/pendidikan nilai pada siswa laki-laki dan perempuan. Dalam kaitannya dengan hal ini, Syarkawitelah mengkaji melalui penelitiannya "Pengarub Pengzunaan Metode Pendidiken Moral terhadap Peningkeacon Pertimbangan Moral Siswa SMP; Study Ekeprimen pada Siswera Siswer SMP".

Syarkawi menguji apakah tingkat pertimbangan moral siswa yang diajar dengan menggunakan metode diskusi dilema moral berdasarkan pada pendekatan perkembangan kognitif berbeda secara signifikan, bila dibandingkan dengansiswa yang diajar dengan metode ceramah-tanya jawab berdasarkan pada pendekatan penanaman nilai?, Apakahtingkat pertimbangan moral yang ditunjukkan kelompok subjek bki-laki berbeda secara signifkan, bila dibandingkan dengan kelompok subjek perempuan'?, dan apakah tendapat pengaruh interaksi antara penggunaan metode diskusi dilema moral atau metode ceramah-tanya jawab dengan jenis kelamin subjek terhadap peningkatan pertimbangan moral siswa? (Syarkawi, hal. 20). ${ }^{1}$ Untuk menemukan jawaban terhadap masalah-masalah tersebut, Syarkawi melakukan eksperimen yang dilaksanakan dengan penggunaan rancangan faktoral $2 \times 2$. bertindaksebagaisubjek penelitian, siswa SMP IKIP Malang. ${ }^{2}$ Pemilihan subjek dan pemberian perlakuan penelitian dilaksanakan secara acak dalam rentang waktu $8 \times$ pertemuan. Alat pengukur tingkat pertimbangan moral siswa yang digunakan oleh Syarkawi adalah struktur tingkat pertimbangan moral yang dikembangkan oleh Kohlberg, sedangkan data yang didapatkan dianalisis dengan menggunakan analisis varian 2 jalur.

\section{B. Orientasi Konseptual}

Dalam melakukan penelitian ini, Syarkawi menggunakan beberapa konsep/teori yang telah dikembangkan oleh beberapa peneliti, antara lain; Aman dkk. ${ }^{3}$ yang mengemukakan bahwa pendidikan moral di sekolah 
dilakukan dengan cara menanamkan hal-hal yang bergunaatautidak berguna, yang baik atau yang buruk, yang benar atau salah, dan semua nilai yang dapat dikembalikan pada kegunaannya, keindahannya, kebaikannya, dan nilai-nilai keagamaan. Hal ini menunjukkan bahwa pendidikan moral di Indonesia selama ini menggunakan pendekatan penanaman nilai, bersifat tradisional, dan mengandung unsur indoktrinasi. Adapun evaluasi yang digunakan adalah berbentuk tes objektif pilihan berganda.

Pendidikan moral yang menitik beratkan kepada usaha-usaha menananamkan berbagai jenis kebaikan secara konkret, dengan contohcontoh, mengajarkan dan menghukum, memuji dan mencela, indoktrinasi, dan ekshortasi (mendesak halus secara insentif, melalui nasihat nasihat, dan peringatan-peringatan), dan kurang menekankan pengembangan penalaran, merupakan ciri pengajaran moral tradisional. Cara-cara seperti ini tampaknya dipraktekkan pada pendidikan moral melalui bidang studi PMP selama ini. Sebaliknya pendidikan moral menekankan pada upaya peningkatan kesanggupan menetapkan pertimbangan moral secara otonom, berpangkal kepada prinsip liberty, equality, dan recipracity belum memperoleh perhatian yang cukup.

Pendidikan moral berdasarkan pendekatan perkembangan kognitif, mengajarkan penalaran moral dan menghendaki lahirnya perilaku moral yang bersumber kepada pertimbangan moral.

Darisini dapat dipahami bahwa pendidikan moral di Indonesia (melalui bidang studi PMP) diajarkan dengan menggunakan pendekatan penanaman nilai melalui metode ceramah-tanya jawab. Cara seperti ini diprediksi kurang mampu mengembangkan tingkat pertimbangan moral, sedangkan penggunaan metode diskusi dilema moral dipredeksi lebih mampu meningkatkan tingkat pertimbangan moral siswa. Di samping itu, variabel jenis kelamin juga dipredeksi mempunyai pengaruh terhadap meningkatnya tingkat pertimbangan moral. Melihat hal demikian, Syarkawi memasukkan 2 variabel bebas untuk diteliti pengaruhnya terhadap variabel tergantung, yaitu penggunaan metode dan variabel jenis kelamin. ${ }^{4}$

Metode diskusi dilema moral yang dimaksudkan oleh Syarkawi adalah 
cara pembelajaran yang digunakan pada bidang studi pendidikan moral, yang dalam penelitiannya adalah bidang studi PPKN, dengan pendekatan perkembangan kognitif dan bertujuan mengembangkan tingkat perkembangan moral siswa. Pelaksanaan metode ini dibagi dalam 3 tahap, yaitu tahapan diskusi kelas sebagai pengantar, diskusi kelompok kecil, dan diskusi kelas sebagai penutup. Dilema moral adalah isu-isu moral yang didalamnya mengandung konflik-konflik nilai sebagai bahan ajar utama dalam menyelenggarakan pendidikan moral. Sedangkan tingkat perkembangan moral adalah kemampuan dalam memberikan alasan-alasan, mempertimbangkan, dan memilih alasan yang paling tepat untuk mengambil keputusan dalam menghadapi moral. Dalam hal ini terdapat 6 tingkatan yaitu; (1) orientasi hukuman dan kepatuhan, (2) orientasi instrumental relatif, (3) orientasi masuk kelompok anak manis, (4) orientasi hukum dan ketertiban, (5) orientasi kontrak sosial legalistik, dan (6) orientasi prinsip kewajiban. ${ }^{5}$

\section{Keunggulan Metode Diskusi Dilema Moral dan Pendekatan Perkembangan Moral}

Pendidikan moral yang diajar dengan menggunakan metode diskusi dilema moral berdasarkan pada pendekatan perkembangan kognitif menunjukkan hasil tingkat pertimbangan moral siswa lebih tinggi, bila dibandingkan dengan siswa yang diajar dengan menggunakan metode ceramah tanya jawab berdasarkan pendekatan penanaman nilai. ${ }^{6}$ Ini berarti, penggunaan metode diskusi dilema moral teruji lebih besar pengaruhnya terhadap proses belajar siswa mengenai hal moral, khususnya dalam pemikiran moral yang terkait dengan tingkat pertimbangan moral. Sebagaimana diketahui bahwa tingkat pertimbangan moral pada hakikatnya dapat mencerminkan moralitas seseorang sehingga dapat diartikan bahwa penggunaan metode diskusi dilema moral dapat meningkatkan moral siswa yang pada gilirannya akan membantu para siswa bermoral lebih baik. 
Pendekatan perkembangan kognitif melalui diskusi dilema moral lebih unggul dalam meningkatkan perkembangan moralitas siswa. Menurut Syarkawi, dikarenakan diskusi dilema moral memiliki dua karakteristik pokok yaitu masalah pendekatan dan masalah metode.

Pendekatan merupakan cara umum dalam memandang permasalahan atau objek suaru kajian. ${ }^{8}$ Cara umum dalam memandang "moral" yang berbeda mendatangkan cara-cara pembelajaran yang berbeda pula. Metode diskusi dilema moral berdasarkan pada pendekatan perkembangan kognitif memandang moral sebagai suatu hal yang rasional dan karenanya harus dipelajari melalui pengembangan kognitif atau cara cara berpikir moral. Kemampuan berpikir moral itu menjadi pijakan berpikir bagi setiap orang dalam menetapkan keputusan moralnya. Oleh sebab itu, moralitas harus dipelajari secara rasional melalui pengembangan kognitif. Karenanya perlu disadari bahwa kehidupan manusia dan perkembangannya tidak dapat dilakukan hanya dengan memberikan contoh-contoh, perintah dan larangan, serta melalui kebiasaan-kebiasaan, sebab perkembangan dan perubahan suatu hal yang tak dapat dihindari dalam kehidupan manusia. Perkembangan dan perubahan yang terjadi itu menimbulkan tantangan -tantangan baru yang harus dihadapi dengan kemampuan berpikir moral yang memadai. Dengan kata lain, tantangan hidup itu hanus dihadapi dengan menggranakan pemikiran yang rasional. Dalam proses berpikir untuk menyelesaikan tantangan itu, setiap orang dituntut untuk menetapkan suatu keputusan moral yang benar dan baik. Setiap keputusan moral yang ditetapkan seseorang, bagaimanapun wujudnya, selalu melalui suatu proses pertimbangan - pertimbangan. Karena itu, menurut pandangan ini belajar moral bertujuan meningkatkan kemampuan seseorang dalam mempertimbangkan keputusan keputusan moralitasnya.

Dalam penelitian Syarkawi ini, pendekatan perkembangan kognitif yang menjadi landasan dalam mengembangkan pendidikan moral melalui metode diskusi dilema moral ini terbukti lebih unggul dalam mempengaruhi proses belajar moral subjek sehingga lebih mampu mempertinggi pencapaian tingkat pertimbangan moralnya, bila dibandingkan dengan pendekatan penanaman nilai yang menjadi landasan dalam mengembangkan pendidikan moral melalui metode ceramah-tanya jawab. Dengan menggunakan pendekatan 
perkembangan kognitif pembelajaran moral terhindar dari kegiatan belajar yang sifatnya hafalan karena belajar moral menghendaki pemahaman dan penalaran. Melalui pemahaman dan penalaran inilah keputusan moral ditetapkan oleh setiaporang sebagai konsekuensi dari hasil belajarnya.

Sebaliknya, pendekatan penanaman nilai-nilai yang dijadikan pijakan pembelajaran moral melalui metode ceramah-tanya jawab adalah kurang mengikutsertakan faktor kognitif. Nilai-nilai moral yang konkret dan peraturanperaturan yang sifatnya telah tetap ditanamkan kepada siswa agar menjadi kebiasaan-kebiasaan yang digandrungi dalam kehidupannya. Dengan demikian, bukan saja nilai-nila moral yang diajarkan itu tidak memadai dalam memecahkan persoalan kehidupan nyata penuh perubahan dan perkernbangan, tetapi juga kurang sesuai dengan hakikat nilai manusia yang sifatnya dinamis dan kneatif. Melalui pendekatan penanaman nilai, langsung atau tidak langsung siswa dihadapkan kepadaindokrrinasi nilai-nilai yang sifatnya mernihak kepada kelompok tertentu dan tidak universal. Nilai-nilai yang diterima siswa cenderung statis dan tidak berkembang ketika mereka menghadapi suatu dilema moral. 9

Dengan demikian perbedaan paling utarna dalam memandang "moral dan cara membelajarkannya" yang diuji dalam penelitian ini melalui penggunaan pendekatan yang berbeda. Pendekatan perkembangan kognitif memandang "moralitas" sebagai suatu hal yang lebih sesuai jika diajarkan secara tidak langsung yakni melalui imposisi dan bantuan "moral discourse", sedangkan pendekatan penanaman nilai menghendaki pembelajaran moral secara langsung, yakni dengan cara menanamkan nilai-nilai moral secara konkret. ${ }^{10}$

Pendekatan perkembangan kognitif berasumsi bahwa pembelajaran moral dengan cara tidak langsung akan mampu menumbuhkan dan mengembangkan cara cara berpikir moral. Sebaliknya, pembelajaran moral dengan cara langsung tidak mampu menumbuhkan dan mengembangkan caracara berpikir moral. Pemikiran moral yang tidak berkembang tidak akan mampu melahirkan perilaku moral yang berpijak pada nilai-nilai kemanusiaan, persamaan, dan keadilan. Sedangkan pendekatan penanaman nilai, memandang "moralitas" sebagai sesuatu yang harus ditanamkan melalui 
pendidikan moral. Seluruh aturan dan nilai-nilai moral yang konkret harus ditanamkan di sekolah oleh guru. Cara ini, selain mengandung unsur indoktrinasi, juga tidak mengikutsertakan secara maksimal pengoperasian faktor kognisi. Karena itu, moralitas tidak dapat tumbuh dan berkembang secara maksimal juga. Hasil penelitian Syarkawi menunjukkan bahwa kelompok siswa yang diajar dengan pendekatan penanaman nilai tidak mampu meningkatkan perkembangan moralnya lebih dari tahap keempat (konvensional). Data menunjukkan ada kecenderungan tidak berkembangnya pemikiran moral, ketika kepada mereka diberikan dilema moral. Sebaliknya, pendidikan moral dengan metode diskusi dilema moral berdasarkan pada pendekatan perkembangan kognitif menunjukkan lebih unggul dalam meningkatkan tingkat perkembangan moral siswa melalui seluruh tes dilema moral yang diberikan. Sebab itu, pendekatan penanaman nilai teruji kurang mampu meningkatkan perkembangan moral siswa. Hal tersebut sesuaidengan teori Kohlberg.

Masalah metode. Pendekatan perkembangan kognitif hanya dapat dikembangkan melalui metode diskusi dilema moral. Karena di kelas pada umumnya siswa berumur relatif sama, maka diskusi itu disebut diskusi dilema moral antar-teman sebaya. Pemanfaatan teman sebaya, mendukung upaya peniadaan unsur indoktrinasi dari pembelajar (guru). Kanena teman sebaya dapat meniadakan unsur indoktrinasi. Siswa merasa memiliki posisi yang sama di antara mereka. Posisi demikian, tidak pernah ada dalam hubungan antara guru dan murid karena kedudukan guru sebagai penencana, pelaksana, dan penilai dalam pembelajaran dan murid sebagai objek yang diajar dan dinilai. Dengan demikian, posisi guru selalu berada pada pihak yang berkuasa dan menentukan. Akibat kedudukan yang demikian, dalam pembelajaran moral siswa dihadapan guru tidak mampu membuka diri secara maksimal atau tidak menunjukkan keterbukaannya.

Dengan demikian, diskusi antar teman sebaya dapat memaksimalkan 'berkembangnya pemikiran moral siswa dalam menetapkan keputusan moralnya. Inilah salah satu alasan mengapa diskusi antar-teman sebaya dapat melahirkan kondisi atau suasana keterbukaan. Dengan kondisi ini, proses belajar dan pertumbuhan pemikimn moral siswa dilakukan atas prakarsa sendiri 
(tidak terintervensi). Siswa dapat berpikir secara optimal dalam diskusi dilema moral. Sebab selain didukung oleh suasana keterbukaan, siswa juga dihadapkan kepada dilema moral yang dapat menyebabkan struktur berpikimya dalam keadaan tidak seimbang (disequilibrium). Ketidakseimbangan iniakan mendorong siswa berusaha mernikirkan kembali dan mencari pemecahan yang lebih sempuma dari kemampuan berpikir yang dimiliki sebelumnya. Kenyataan ini membuat siswa lebih mampu mencapai tingkat pertimbangan moral ke arah yang lebih tinggi dan pada gilirannya juga akan lebih mampu menghadapi tantangan moralitas yang semakin kompleks.

Dalam pendekatan penanaman nilai, nilai disampaikan melalui metode ceramah-tanya jawrab antara siswa dengan guru dengan bahan ajar nilai-nilai moral secara konkret. Siswa harus menerima apa yang diceramahkan oleh guru dan atau yang diinformasikan oleh buku teks dan kemudian dihafalkan. Penghafalan nilai-nilai dan perilaku moral perlu dilakukan siswa untuk menjawab soal ujian yang menuntut tingkat pengetahuan tentang nilai-nilai yang diajarkan. Karena itu, pendidikan moral cara ini menuntut pengetahuan, pemahaman, dan mungkin penghayatan nilai-nilai yang diajarkan. Dengan demikian, cara ini tidak menuntut kemampuan berperilaku moral sebagai tagihan dari tujuan yeng sebenanya dalam pendidikan moral. Mungkin secara kuantitas, siswa banyak mengetahui tentang peranuran-peraturan konkret yang diinformasikan, akan tetapi apakah ada jaminan dengan "mengetahui peraturan itu" secara otomatis akan mampu mengaplikasikan dalam tuntutan moralitas yang sebenannya Menurut Syarkawi, ternyata melalui penelitian ini ditemukan pengaruh penggunaan metode ceramah-canya jawab terhadap peningkatan tingkat perkembangan moral lebih rendah pencapaiannya bila dibandingkan dengan penggunaan metode diskusi dilema moral. Sebagaimana dikemukakan oleh Kohlberg (1971) ${ }^{11}$ tingkat pertimbangan moral yang rendah secara konsisten dapat menunjukkan rendahnya moralitas seseorang. Dengan demikian berarti, penggunaan metode ceramah-tanya jawab kurang mampu meningkankan pemikian moral siswa sebagaimana yang ditunjukkan oleh data penelitian. 


\section{Pendekatan dan Metode}

Deskripsi hasil penelitian yang dilakukan Syarkawi ini memisahkan antara pendekatan dan metode yang digunakan dalam pembelajaran. Menurut Syarkawi hal ini dilakukan karena perbedaan cara pandang (pendekatan) antara yang satu dengan yang lain sekaligus mengakibatkan perbedaan dalam menetapkan metode yang digunakan. ${ }^{12}$ Karena itu, penguraian yang memisahkan antara pendekatan dan metode dilakukan hanya untuk melihat kelebihan dan kekurangan secara lebih teliti pada masing-masing bagian. Artinya, walau diuraikan secara terpisah antara pendekatan dan metode yang digunakan dalam pendidikan moral, tetapi pada hakikatnya tetap merupakan satu kesatuan.

\section{E. Keunggulan Kelompok Perempuan dan Laki-laki}

Kelompok subjek perempuan lebih unggul dalam pencapaian tingkat perkembangan moral, bila dibandingkan dengan kelompok subjek laki-laki. Ini berarti, perbedaan jenis kelamin subjek berpengaruh terhadap proses belajar moral, baik untuk pendidikan moral yang menggunakan metode diskusi dilema moral maupun metode ceramah-eanya jawab. Penelitian ini mendukung temuan penelitian sebelumnya yang menyatakan bahwa perkembangan tingkat pertimbangan moral juga dipengaruhi oleh faktor jenis kelamin subjek. ${ }^{13}$

Dalam hal moral subjek perempuan dianggap memiliki pemikiran lebih representatif dari pada subjek laki-laki. ${ }^{14}$ Dilihat dari mekanisme kerja emosi yang dihubungkan dengan perasaan jauh dan dekatnya dilema moral yang dimanipulasi, subjek perempuan ternyata lebih tanggap bila dibandingkan dengan subjek laki-laki. ${ }^{15}$ Dilihat dari segi persepsi, ekspresi, dan peran berperilaku dalam dilema moral, diketahui bahwa subjek laki-laki cenderung lebih tahan dan kurang suka membantu, bila dibandingkan dengan subjek perempuan, sehingga subjek perempuan cenderung memilih tingkat pertimbangan moral lebih tinggi daripadasubjek laki-laki. ${ }^{16}$ 


\section{F. Interaksi Pengaruh Penggunaan Metode dan Jenis Kelamin terhadap Peningkatan Pertimbangan Moral}

Penggunaan metode diskusi dilema moral teruji lebih unggul dalam pencapaian tingkat pertimbangan moral, bila dibandingkan dengan penggunaan metode ceramah-tanya jawab. Walaupun pencapaian tingkat pertimbangan moral kelompok subjek perempuan lebih unggul, bila dibandingkan dengan kelompok subjek laki-laki, akan tetapi dengan terujinya ketidakadaan interaksi antara penggunaan metode dengan faktor jenis kelamin maka berarti penggunaan metode diskusi dilema moral lebih baik daripada penggunaan metode ceramah-tanya jawab terlepas dari jenis kelamin subjek yang menggunakan metode tersebut.

Dengan demikian, temuan ini mendukung temuan penelitian sebelumnya yang menyatakan tidak ada bias karena perbedaan jenis kelamin dalam penggunaan metode diskusi dilema moral. ${ }^{17}$

Temuan penelitian keunggulan penggunaan metode diskusi dilema moral dalam meningkatkan pertimbangan moral siswa dan yang teruji bebas dari pengaruh jenis kelamin ini sahih menurut syarat - syarat penelitian, baik internal maupun eksternal. Secara internal, seluruh variabel yang diduga akan mempengaruhi variabel tergantung telah dikontrol melalui rancangan penelitian. Secara eksternal, variabel-variabel yang diduga akan berpengaruh terhadap variabel tergantung telah diusahakan agar tetap konstan. Karena itu, ditinjau dari segi pelaksanaan penelitian temuan yang dihasilkannya memilikinilaikesahihan sebatas yang dipersyaratkan dalam bidang keilmuan.

\section{G. Kesimpulan}

Temuan penelitian iniadalah: (1) tingkat pertimbangan moral siswa yang diajar dengan menggunakan metode diskusi dilema moral yang dikembangkan berdasarkan pendekatan perkembangan koknitif berbeda secara signifikan, bila dibandingkan dengan siswa yang diajar dengan metode ceramah tanya- 
jawab yang dikembangkan berdasarkan pendekatan penanaman nilai. Dalam hal ini, tingkat pertimbangan moral siswa yang diajar dengan menggunakan metode diskusi dilema moral lebih unggul dari pada siswa yang diajar dengan metode ceramah tanya-jawab., (2) tingkat pertimbangan moral subjek lakilaki berbeda secara signifikan, bila dibandingkan dengan subjek perempuan, dalam hal ini tingkat pertimbangan maral subjek perempuan lebih unggul dari pada subjek laki-laki, dan (3) tidak terdapat interaksi antara penggunaan metode dengan jenis kelamin terhadap tingkat pertimbangan moral siswa. Dengan demikian, pengaruh metode pendidikan moral yakniceramah tanyajawab dan diskusi dilema moral terhadap tingkat pertimbangan moral siswa bebas dari pengaruh jenis kelamin siswa.

Berdasarkan temuan penelitian, dikemukakan saran yaitu; Dengan terujinya secara empiris keuggulan penggunaan metode diskusi dilema moral terhadap peningkatan pertimbangan moral siswa, bila dibandingkan dengan metode ceramah tanya-jawab yang dipraktekkan di sekolah selama ini, maka perlu kiranya para penentu kebijakan bidang pengembangan kurikulum mempertimbangkan penggunaan metode diskusi dilema moral yang berdasarkan kepada pendekatan perkembangan koqnitif melalui program difusi pembahanuan metodologi pendidikan moral dan pendidikan nilai. Untuk menggunakan metode ini kedalam selunuh jam pelajaran pendidikan moral dan pendidikan nilai (agama) yang tersedia di sekolah tampaknya belum memungkinkan. Untuk itu, penggunaan dapat dilakukan minimal satu kali pembelajaran dalam satu catur wulan. Hal ini disadari karena penggunaan metode diskusi dilema moral meliputi masalah pendekatan yang penggubahannya memerlukan kajian yang lebih mendalam dan komprehensif. Untuk itu, metode ini dapat digunakan untuk pendidikan moral dan pendidikan nilai (agama) di sekolah secara insidental.

Dalam menggunakan metode diskusi dilema moral, seyogyanya memperhatikan jenis kelamin subjek. Maksudnya, dalam suatu kelompok diskusi perlu dilibatkan jenis kelamin subjek yang berbeda (laki-laki dan Perempuan). Hal inipenting dilakukan karena telah teruji secara empiris bahwa subjek perempuan lebih unggul dalam pencapaian tingkat perkembangan moral bila dibandingkan dengan laki-laki. Perbedaan tersebut akan mendorong 
terjadinya disequilibrium dalam pemikiran moral para peserta diskusi (lakilaki dan perempuan).

Mengingat penelitian ini dirancang hanya melibatkan kelompok subjek yang menganut suatu agama.tertentu yakni Islam, maka keyakinan keagamaan dapat diduga juga berpengaruh terhadap cara - cara pemikiran dan perilaku moral seseorang. Untuk itu, dalam meningkatkan kesahihan internal temuan penelitian maka perlu dilakukan penelitian lanjutan yang melibatkan subjek dari berbagai agama, atau dengan memasukkan lebih banyak variabel bebas seperti status sosial-ekonomi orangtua, dan sejenisnya. Disamping itu, dalam rangka meningkatkan kesahihan internal temuan penelitian maka perlu juga dilakukan penelitian lanjutan dengan menggunakan desain pembelajaran moral yang hanya menggunakan metode diskusi dilema moral, dibandingkan dengan pembelajaran yang menggunakan kombinasi metode diskusi dilema moral dan ceramah tanya-jawab dan atau memperluas pelibatan kelompok subjek pembanding yang ekuivalen dari lembaga sekolah yang berbeda dengan guru pengajar yang sama. Hal ini penting dilakukan agar benar-benar dapat dipercaya bahwa subjek tidak mengadakan interaksi belajar dengan subjek yang lain selama penelitian berlangsung.

\section{H. Kritik dan Alternatif}

Tanpa mengurangi artikelebihan dan nilai pentingnya hasil penelitian ini, sebagai kritik membangun dan saran perbaikan, maka berikut ini akan disajikan kelemahan-kelemahan yang, terdapat dalam laporan penelitian Disertasi Syarkawi ini yang masih memerlukan perbaikan dan perhatian meliputi, aspek rancangan eksperimen yang dipakai, penentuan populasi dan sampel penelitian, instrumen penelitian yang digunakan, dan teknik analisis data.

Kelemahan-kelemahan yang nampak dalam rancangan penelitian Disertasi ini adalah bahwa rancangan eksperimen yang digunakan tidak mengungkapkan tentang bagaimana hasil pre-tes sebelum diberikan 
perlakuan. Hal ini dimaksudkan untuk mengetahui bagaimana kondisi masing-masing rata - rata siswa sebelum diberikan perlakuan dan pengaruh perlakuan yang akan dilihat dalam pasca tes. Eksperimen yang dilakukan dalam disertasi ini adalah randomisasi, yang digunakan untuk menentukan sampel siswa laki-laki dan perempuan, kemudian perlakukan dan dilanjutkan dengan pasca tes. Hal ini dapat dilihat dengan diagram 01 sebagai berikut:

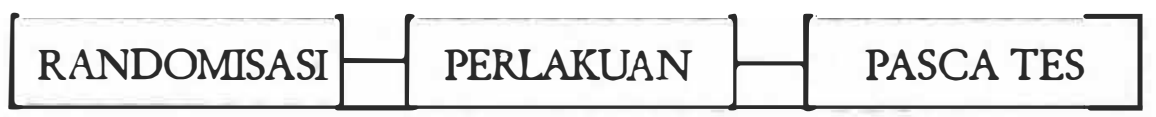

Diagram 01:Pedaseraan Eesperimen Diadaptasi dari

Syarkawi, hal. 93/ ${ }^{\text {hs }}$

Menurut penulis (perevieu) rancangan eksperimen yang seharusnya digunakan adalah, Randomisasi, kemudian pre-tes dan selanjutnya perlakuan dan pasca tes. Hal ini dapat dilihat pada diagram 02 berikut ini:

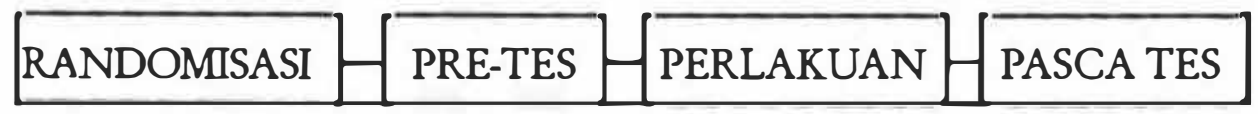

(Diagram 02: Rencengan Ekeperimen yang disarankan olehpenulis (pereview).

Rancangan tersebut dapat dijabarkan secara lengkap dalam Diagram 03 sebagai berikut ini; 
Diagram 03: Rencongan Eleperinen yang disarankan oles penulis (perevieul)

\begin{tabular}{|c|c|c|c|c|c|c|c|}
\hline \multirow{3}{*}{\multicolumn{2}{|c|}{$\begin{array}{c}\text { Jenis } \\
\text { Kelamin }\end{array}$}} & \multicolumn{6}{|c|}{ METODE } \\
\hline & & \multirow{2}{*}{\multicolumn{3}{|c|}{$\begin{array}{l}\text { Ceramah - Tanya Jawab } \\
\text { Pre - Tes Perlakuan Pasca Tes }\end{array}$}} & \multirow{2}{*}{\multicolumn{3}{|c|}{$\begin{array}{c}\text { Diskusi Dilema Moral } \\
\text { Pre - Tes Perlakuan Pasca Tes }\end{array}$}} \\
\hline & & & & & & & \\
\hline \multirow{2}{*}{ Lk } & Eks. & $\mathrm{T} 1$ & $x$ & $\mathrm{~T} 2$ & T1 & $\mathrm{x}$ & $\mathrm{T} 2$ \\
\hline & Kont. & $\mathrm{T} 1$ & - & $\mathrm{T} 2$ & T1 & - & $\mathrm{T} 2$ \\
\hline \multirow{2}{*}{ Pr. } & Eks. & $\mathrm{T} 1$ & $x$ & $\mathrm{~T} 2$ & $\mathrm{~T} 1$ & $\mathrm{X}$ & $\mathrm{T} 2$ \\
\hline & Kont. & T1 & - & T2 & T1 & - & $\mathrm{T} 2$ \\
\hline
\end{tabular}

Diadaprasi dari M. Djunaidi G, 1986, hal. 102; 1988, hal. 254)'

Instrumen yang dibuat oleh Syarkawi ${ }^{20}$ untuk didiskusikan oleh para siswa SMP kurang sesuai dengan tingkat usia siswa SMP. Deskripsi peranypanpertanyaan yang disajikan sebagai instrumen untuk didiskusikan oleh siswa lebih bantyak mengkisahkan orang tua, atau Dokter sebagai aktor pelakurya Hal ini tentu saja kurang sesuai dengan tingkat perkembangan usia siswa dan juga tingkat perkembangan moral siswa karena Kohlberg sendiri di dalam mengukur ingkar perkembangan moral siwa juga mempervimbangkan tingkr usia siswa (anak). Dengan demikian, para aktor/pelaku yang dimainkan dalam cerita cerita dilema moral/peranyasn pereanyan yang akan didiskusikan perlu memperti mbangkantingkat usia siswa.

Sedangkan reliabilizas tes yang digunakandalam penelition ini kualitasnya masih rendah karena peneliti tidak menindak lanjuti jawaban-jawaban yang diberikan oleh siswa. Disamping itu, penetapan sampel tidak mempertimbangkan latar belakang keluarga siswa yang menjadi sampel. Oleh sebab itu, penulis (perevieu) mensarankan agar pelaksanaan penelitian sebagai 
tindak lanjut dari disertasi ini perlu mengikut sertakan dan mempertimbangkan latar belakang keluarga sampel dan agamanya. Dan akan lebih baik, juga mempertimbangkan lingkungan sekolah/latar belakang sekolah tempat sampel belajar. 


\section{Notes:}

1. Lihat Syarkawi, hal. 20

2. Ibid, hal. 75-76.

3. Aman dkk., 1985., Values Education in Indonesia, (Jakarta: Department of Education $8 x$ Culture Indonesia).

4. Syarkawi, op.cit, hal.77-79.

5. Ibid, hal. 25-27.

6. Ibid, hal. 114-115.

7. Ibid, hal. 115 .

8. Raka Joni, T., Cara Belajar Siswa Aktif, CBSA: Artikulasi Konseptual,Jabaran Operasional, dan Veritifikasi Empirik. (Malang: Forum Penelitian, Pusat Penelitian IKIP Malang, 1990).

9. Maramis, Irsan, K., "Bukan kạrena gaji, tapisoal moral”, Oawa Pos, hlm.1, 22 Agustus 1993).

10. Syarkawi, op.cit, hal. 118.

11. Lihat Kohlberg 1971.

12. Syarkawi, op.cit, hal. 122.

13. Lihat Beloff dan Temperly, 1970; Gilligan, 1982; Ford dan Lowery, 1986; Tucker dan Locke 1986; dan Frijda, 1988.

14. Lihat Gilligan, 1982.

15. Lihat Tucker dan Locke, 1986; dan Frijda, 1988.

16. Lihat Ford dan Lowery, 1986.

17. Lihat Han, 1986.

18. Syarkawi, op.cit, hal. 93.

19. M. Djunaidi, G., Pedoman di Dalam Penelitian dan Penilaian, (Surabaya: Usaha Nasional, 1986),102. M. Djunaidi, G. Dasardasar Renelizin Eksperimen: untuk bidang Kedokteran, Farmasi, Pendidikan, Psikologi sosiologi dan lainnya, (Surabaya. Usaha Nasional, 1988), 254.

20. Syarkawi, op.cit, hal. 279-292. 


\section{Bibliography}

Aman, dkk.., 1985, Values Education in Indoneri, Jakara: Deparement of Education \& Culture Indonesia.

Ardhana, W., 1985, "Keefekrifan pendidikan momal bendasarkan beberapa bukti empirik" Makalah ditacakan pach Ridato Lektorat didepan Sidang Senat Terbutea FIP IKIP MALANG, Malang: 24 Agurous 1985.

Ford, M.R., dan Lowery, C. M., 1986, "Gender differences in Moral ressoning: A Comparison of the use of jostice and care orientations", Joumal of Personality and Sacial By trology, 50 (4): $777-783$.

Irsan, K., 22 Agurous 1993, "Bukan karena gaji, tapi soal moma", Jawa Pos, bah 1.

G., M.Djunaidi 1986, Redomen di Dalam Rnelitian dan Pnilaian, Surabaya: Usaha Nasional.

— 1988, Dasardasar Penelitian Eksperinen' untuk bidang Kedokteran, Farmasi,

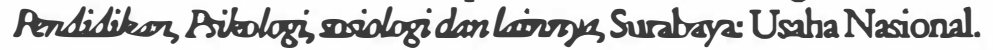

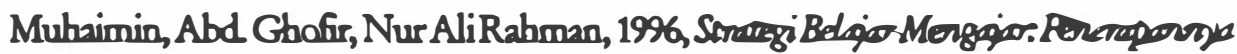
dalom penbedianeo PAI, Surbayz Adios Media

Raka Joni, T., 1990, Cara Belajar Sirera Aktif, CBSA:A rikulari Konseptual, Jabaran Operasionel dan Veritifleasi Empinits Malang. Fonum Perelinan, Pusar Penelitian IKIP Malang. 